\title{
Intervascular pit membranes with a torus in the wood of Ulmus (Ulmaceae) and related genera
}

\author{
Steven Jansen ${ }^{1}$, Brendan Choat $^{2}$, Stefan Vinckier ${ }^{1}$, Frederic Lens ${ }^{1}$, Peter Schols ${ }^{1}$ and Erik Smets ${ }^{1}$ \\ ${ }^{1}$ Laboratory of Plant Systematics, K.U.Leuven, Institute of Botany and Microbiology, Kasteelpark Arenberg 31, B-3001 Leuven, Belgium; ${ }^{2}$ Department of \\ Organismic and Evolutionary Biology, Harvard University, Cambridge, MA 02138, USA
}

\section{Summary}

Author for correspondence:

Steven Jansen

Tel: +32 16321539

Fax: +3216321968

Email: steven.jansen@bio.kuleuven.ac.be

Received: 19 January 2004

Accepted: 15 March 2004

doi: 10.1111/j.1469-8137.2004.01097.x
- The distribution of intervascular pit membranes with a torus was investigated in juvenile wood samples of 19 species of Ulmus and seven related genera.

- A staining solution of safranin and alcian blue (35:65) was recommended to distinguish torus-bearing pit membranes using light microscopy.

- Intervascular pit membranes connecting relatively wide vessel elements resembled those of most angiosperms, as they were of uniform thickness. By contrast, bordered pit pairs with round to oval pit apertures and indistinct pit canals that connected narrow (incomplete) vessel elements or vascular tracheids with distinct helical thickenings were frequently characterized by a torus in ring-porous wood samples of Ulmus and Zelkova. Tori were lacking in diffuse-porous species of Ampelocera, Aphananthe, Gironniera, Holoptelea, Phyllostylon, Trema and Ulmus.

- Our observations suggest that tori are more common in cold temperate climates than in warm (sub)tropical environments. This may indicate that narrow tracheary elements with torus-bearing pit membranes provide an auxiliary conducting system which is of low conductivity, but offers greater resistance to freezing-induced cavitation.

Key words: Ulmus (elm), Ulmaceae, pit membrane, torus, pit structure, wood anatomy, tracheary elements.

(C) New Phytologist (2004) 163: 51-59

\section{Introduction}

As water moves primarily from vessel to vessel or from tracheid to tracheid, the pit structure plays an important role in water transport in living plants, but it also affects the drying of wood and its treatment with preservatives (Schmid, 1965; Bauch et al., 1972). Micromorphological studies illustrate that there is a wide structural variety associated with pits in tracheary elements, for instance with respect to pit size, shape, depth of pit chamber, pit-field arrangement and presence of vestures (Frost, 1931; Liese, 1965; Schmid, 1965; Jansen et al., 2001). Recent findings highlight the importance of pit membranes in pit function, especially with respect to flow resistance and cavitation vulnerability (Tyree \& Sperry, 1989; Cochard et al., 1992; Zwieniecki et al., 2001; Becker et al., 2003; Choat et al., 2003; Sperry, 2003). Pit membranes can be considered to act as finely porous filters, allowing the flow of water and nutrients, but at the same time limiting the passage of air bubbles and pathogens between adjacent tracheary elements.
While the basic structure and function of bordered pit membranes of softwoods is fairly well understood (Bauch et al., 1972; Fengel, 1972; Booker, 1992; Sano et al., 1999), our understanding of angiosperm pit membranes is based on an extremely small fraction of species (Ohtani, 1983; Wheeler, 1983; Sano \& Fukazawa, 1994). Therefore structural variation in pit membranes of hardwood species is not fully understood, and additional observations are required.

Pit membranes with a torus, which is defined as the central thickening of an intervascular pit membrane, are known to be a characteristic feature of tracheid pits in conifers. Tori are found in many, but not all, genera of gymnosperms (Bauch et al., 1972). Although pit membranes of angiosperms are of uniform thickness and lack visible openings, tori were reported for the first time in angiosperms in the intervascular pits of Daphne (Thymelaeaceae) and Osmanthus (Oleaceae) (Schmid, 1965; Schmid \& Machado, 1968; Ohtani \& Ishida, 1978). This character was found subsequently in two species of Ulmus (Ulmaceae) and three species of Celtis (Cannabaceae 
sensu APG II) (Wheeler, 1983; Dute \& Rushing, 1990; APG II, 2003). Moreover, 'torus-like' structures were reported in interfibre pits of Prunus and Pyrus (both Rosaceae) as well as for intervascular pit membranes of Ligustrum (Oleaceae) (Parameswaran \& Gomes, 1981; Parameswaran \& Liese, 1981; Barnett, 1987). Dute \& Rushing $(1987,1988,1990)$ and Dute et al. $(1990,1992,1996,2001)$ have focused specifically on the development and ultrastructure of torus-bearing pit membranes in angiosperms. It is clear that tori have evolved several times in some highly specialized angiosperms, because the feature has been reported in species belonging to Rosales, Malvales and Lamiales according to the APG II classification (APG II, 2003). The homoplastic nature of tori in angiosperms is probably caused by functional adaptations, but the ecological and physiological significance of these tori are not fully understood.

So far tori have been observed with light microscopy (LM) and electron microscopy (TEM, SEM) in two species of Ulmus (Ulmus alata and Ulmus thomasii), while the feature was found to be lacking in Ulmus americana (Wheeler, 1983; Dute \& Rushing, 1990). Although most studies on the wood structure of Ulmaceae did not comment on torus-bearing pit membranes (Sweitzer, 1971; Zhong et al., 1992), tori may be common in numerous representatives of this family. It seems that tori may easily be overlooked during LM observations of wood sections, because micromorphological details of pits are usually difficult to observe accurately. Therefore counterstaining is desirable to maximize the observation of minute pit features with LM. With this consideration in mind, we initiated an investigation of bordered pit pairs of $19 \mathrm{elm}$ species. Also included were five related genera of Ulmaceae, and two genera that were previously placed in Ulmaceae but are now incorporated in Cannabaceae (APG II, 2003). An oil-immersion objective of a light microscope and a simple mixture of two staining solutions were shown to be sufficiently appropriate for LM observation of tori in wood sections. This paper is part of ongoing studies on the micromorphological structure of pits (Jansen et al., 1998b, 2001, 2003).

\section{Materials and Methods}

Young stem segments were collected from dried herbarium material of the National Botanic Garden of Belgium. A specimen of Ulmus laciniata was collected from the Arnold Arboretum of Harvard University. The diameter of all wood samples studied was $<1.5 \mathrm{~cm}$. The nomenclature of all species followed the currently accepted species delimitation according to the International Plant Names Index of the Plant Names Project (www.ipni.org).

The following species (with reference to their origin and collector) were investigated: Ampelocera dichotoma Mildbr. ex Baehni, Peru, Loreto, Maynas, M. Rimachi Y. 6565; Aphananthe aspera Planch., Japan, Kagawa, D. Champluvier 5469; Gironniera celtidifolia Gaudich., Philippine Islands, Surigao, C.A. Wenzel
3149; Holoptelea integrifolia Planch., Sri Lanka, Thwaites 2381; Phyllostylon rhamnoides (Poiss.) Taub., Argentina, Palo de Lauza, Corrientes, Troels Myndel Pedersen 2793a; Trema lamarckiana Roem. \& Schult., Puerto Rico, Sintensis 3902; Ulmus campestris L., France, Bourges, A. Déséglise 1763; U. campestris L., Greece, Crete, Montagnes de Lelfa Ori, R. Dechamps 9047; U. campestris L., France, Côte d'Or, between Pont-de Pany and Arcey, J. Callé s.n.; U. campestris L., France, Le Puy, Velay, collector unknown; Ulmus carpinifolia Gled., UK, Hertsfordshire, Cottered Green, R. Melville s.n.; Ulmus coritana var. coritana Melville, UK, Oxfordshire, Banbury, R. Melville \& J.C. Went 38.68; Ulmus cornubiensis Weston var. goodgeeri Melville, UK, Hampshire, New Bashley, R. Melville 37.123; Ulmus davidiana Planch. var. japonica Nakai forma suberosa Nakai, Japan, Nagano, Mt. Asama, Kitasaku-gun, T. Makino 19602; Ulmus diversifolia Melville, UK, Hertsfordshire, Hatfield, R. Melville 36.265; Ulmus effusa Willd., France, Bois de Raismes, A. Lelièvre s.n.; Ulmus fulva Michx., USA, Missouri, Jackson, Beug Park, B.F. Bush 882; Ulmus glabra Huds., Bulgaria, Barzya, Stara Planina, H. Beeckman bu50; Ulmus japonica Sarg., China, Chihli, Huai lai, Yang kia ping, J. Hers 2108; Ulmus laciniata Mayer, Japan, Hyôgo, Hyônosen, Mikata-kôgen, T. Yamazaki \& H. Kanai 10964; U. laciniata Mayer, USA, Arnold Arboretum of Harvard University, ASI, 26-NE, accession number 17909-B; Ulmus lancifolia Roxb. ex Wall., Indonesia, Lesser Sunda Islands, W. Flores, Manggarai, E. Schmutz 4945; Ulmus macrocarpa Hance, China, Shansi, J. Hers 2016; Ulmus mexicana (Liebm.) Planch., Mexico, Landa de Matamoros, Queretaro, S. Zamudio s.n.; Ulmus montana With., France, Givet, C. Vanden Berghen \& D. Duvigneaud s.n.; Ulmus parvifolia Jacq., Japan, Tatebayashi, Gumma, T. Makino 19467; Ulmus pedunculata Foug., France, Forêt de Mormal, J. Duvigneaud 64F 468; Ulmus plotii Druce, UK, Bedfordshire, Pegzodon, R. Melville \& H.K. Riry-Shaw 46.12 A; Ulmus scabra Mill., Belgium, Vilvoorde, Ecole d'horticulture, collector unknown; U. scabra Mill., France, Sainte-Eugrâce, C. Vanden Berghen s.n.; Zelkova acuminata Planch., Japan, Hondo, Honaimura, Yechigo, M. Togasi 590; Zelkova crenata Spach, Belgium, Nimy, A. Wesmael s.n.

Longitudinal and transverse sections $(10-15 \mu \mathrm{m}$ thick) were sectioned from dried stem segments using a sliding microtome (Reichert, Vienna, Austria) (Jansen et al., 1998a). A mixture of safranin and alcian blue $(35: 65)$ was used as staining solution. This counterstaining solution was found to be most useful for light microscopic observations of pits. The safranin was prepared as a $1 \%$ solution in $50 \%$ ethanol. The $1 \%$ alcian blue stain was dissolved in deionized water. After staining, sections were washed in deionized water, dehydrated in an alcohol series, treated with the clearing agent Parasolve (Prosan n.v., Merelbeke, Belgium) and embedded in Euparal (Agar Scientific Ltd, Essex, UK).

In order to verify the true nature of tori in sections prepared according to the method above, semi-thin sections of 
New

Phytologist

Table 1 Distribution of intervascular pit membranes with a torus in Cannabaceae and Ulmaceae, with reference to correlated wood anatomical features and their origin

\begin{tabular}{|c|c|c|c|c|c|}
\hline Family/species (number of specimens studied) & Torus & Porosity & HT & VT & Origin of specimens studied \\
\hline \multicolumn{6}{|l|}{ Cannabaceae } \\
\hline Trema lamarckiana (1) & - & DP & - & - & Puerto Rico \\
\hline Gironniera celtidifolia (1) & - & DP & - & - & Philippine Islands \\
\hline \multicolumn{6}{|l|}{ Ulmaceae } \\
\hline Ampelocera dichotoma (1) & - & DP & - & - & Peru \\
\hline Aphananthe aspera (1) & - & DP & - & - & Japan \\
\hline Holoptelea integrifolia (1) & - & DP & - & - & Sri Lanka \\
\hline Phyllostylon rhamnoides (1) & - & DP & - & - & Argentina \\
\hline Ulmus campestris (4) & + & $\mathrm{RP}$ & + & + & France; Crete \\
\hline Ulmus carpinifolia (1) & + & $\mathrm{RP}$ & + & + & UK \\
\hline Ulmus coritana var. coritana (1) & + & $\mathrm{RP}$ & + & + & UK \\
\hline Ulmus cornubiensis var. goodgeeri (1) & + & $\mathrm{RP}$ & + & + & UK \\
\hline Ulmus davidiana var. japonica forma suberosa (1) & + & $\mathrm{RP}$ & + & + & Japan \\
\hline Ulmus diversifolia (1) & + & $\mathrm{RP}$ & + & + & UK \\
\hline Ulmus effusa (1) & + & $\mathrm{RP}$ & + & + & France \\
\hline Ulmus fulva (1) & + & $\mathrm{RP}$ & + & + & USA \\
\hline Ulmus glabra (1) & + & $\mathrm{RP}$ & + & + & Bulgaria \\
\hline Ulmus japonica (1) & + & $\mathrm{RP}$ & + & + & China \\
\hline Ulmus laciniata (2) & + & $\mathrm{RP}$ & + & + & Japan; cultivated in USA \\
\hline Ulmus lancifolia (1) & - & $\mathrm{DP}$ & - & - & Indonesia \\
\hline Ulmus macrocarpa (1) & + & $\mathrm{RP}$ & + & + & China \\
\hline Ulmus mexicana (1) & - & $\mathrm{DP}$ & + & + & Mexico \\
\hline Ulmus montana (1) & + & $\mathrm{RP}$ & + & + & France \\
\hline Ulmus parvifolia (1) & + & $\mathrm{RP}$ & + & + & Japan \\
\hline Ulmus pedunculata (1) & + & $\mathrm{RP}$ & + & + & France \\
\hline Ulmus plotii (1) & + & $\mathrm{RP}$ & + & + & UK \\
\hline Ulmus scabra (2) & + & $\mathrm{RP}$ & + & + & France; cultivated in Belgium \\
\hline Zelkova acuminata (1) & + & $\mathrm{RP}$ & + & + & Japan \\
\hline Zelkova crenata (1) & + & RP & + & + & Belgium \\
\hline
\end{tabular}

Family classification follows APG II (2003); DP, diffuse-porous; RP, ring-porous; HT, helical thickenings confined to narrow tracheary elements; VT, vascular tracheids; +, present; -, absent.

U. campestris, U. laciniata, U. lancifolia, U. parvifolia and $Z$. crenata were prepared of material embedded in LR White Resin (Polysciences Inc., Warrington, PA, USA). Young stem segments were fixed with $2 \%$ glutardialdehyde at $\mathrm{pH} 7.3$ and buffered with 0.05 m sodium cacodylate. Before embedding in LR White Resin, the material was dehydrated in a graded ethanol series and block-stained with $1 \%$ phosphotungstic acid in $100 \%$ ethanol. Semi-thin $( \pm 4 \mu \mathrm{m})$ sections were cut with glass knives using an Ultracut $\mathrm{E}$ microtome (Reichert, Vienna, Austria) and stained with $0.1 \%$ thionin $-0.1 \%$ methylene blue.

Observations were carried out using a Dialux 20 light microscope (Leitz, Wetzlar, Germany). In order to provide detailed information about the pit geometry, measurements of $U$. laciniata were conducted on LM images using CARNOY 2.0 software (Schols et al., 2002). Quantitative data for sliding microtome sections of this species were based on counts of 50 measurements. The ratio of the short to long axes of pit apertures and pit borders was used as a measure of circularity. Pictures were taken using a DP50-CU digital camera (Olympus, Hamburg, Germany). Terminology follows the International
Association of Wood Anatomists' list of microscopic features for hardwood identification (IAWA Committee, 1989).

\section{Results}

Intervascular pit membranes with a torus were present in 17 ring-porous wood species of Ulmus and two ring-porous species of Zelkova (Table 1; Fig. 1a,c-e). Although the resolution of micromorphological pit structures was usually higher in semi-thin sections (Fig. 1d) than in relatively thick sections prepared with the sliding microtome (Fig. 1c), the presence or absence of tori could be determined in all sections prepared with the sliding microtome. The staining solution of safranin and alcian blue generally resulted in a dark blue colour of tori in contrast to the margo, which was practically invisible. Tori were most distinctly present in $U$. laciniata (Fig. 2a-c,f), U. montana, U. scabra (Fig. 1c) and most specimens of U. campestris (Fig. 1d), while they could hardly be seen in longitudinal sections of $U$. cornubiensis var. goodgeeri. Species of Ulmus lacking tori included U. lancifolia (Fig. 1f) and U. mexicana (Fig. 1b), which showed diffuse-porous wood 

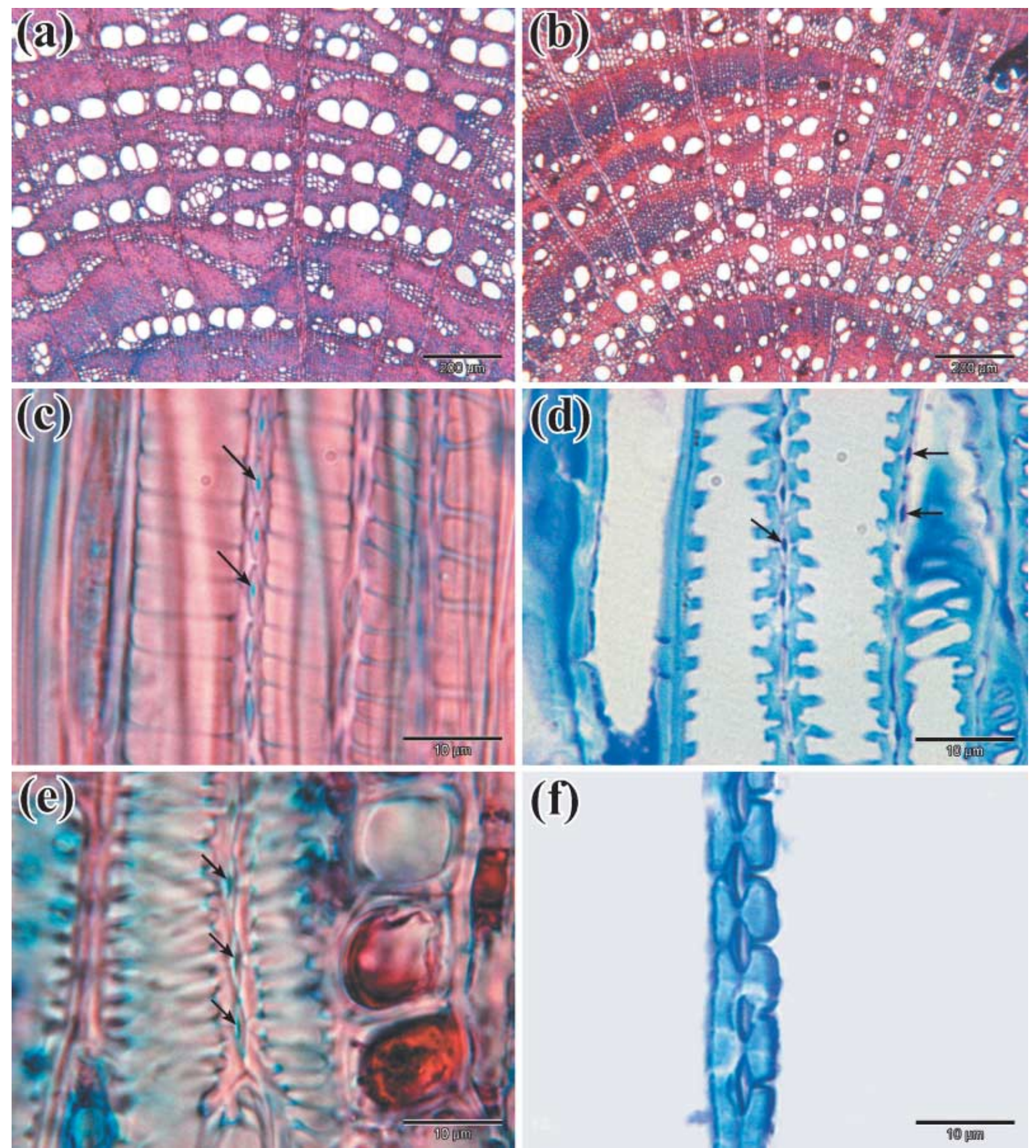

(f)

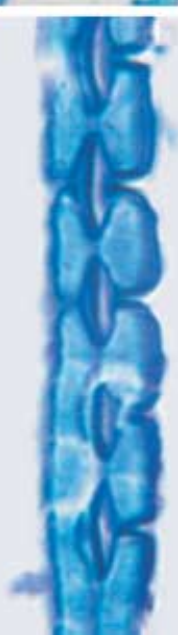

990 幽

Fig. 1 Light microscopic illustrations of wood of Ulmus and Zelkova. All sections are 10-15 $\mu \mathrm{m}$ thick and stained with safranin and alcian blue, except for (d) and (f) which are semi-thin sections, stained with thionin-methylene blue. (a) Transverse section showing ring-porous wood of Ulmus diversifolia with wide vessels in earlywood and narrow tracheary elements in latewood. (b) Transverse section of Ulmus mexicana showing diffuse-porous wood and indistinct growth rings. (c) Radial longitudinal section of narrow tracheary elements with helical thickenings and tori (arrows). (d) Radial longitudinal section of Ulmus campestris showing intervascular pit membranes with tori (arrows) associated with bordered pits of narrow tracheary elements. (e) Tangential longitudinal section of Zelkova crenata with tori (arrows) in intervascular pits of two narrow tracheary elements. (f) Tangential longitudinal section of Ulmus lancifolia. Note the presence of a relatively thick vessel wall, pit canal and intervascular pit membranes without a torus. 
New
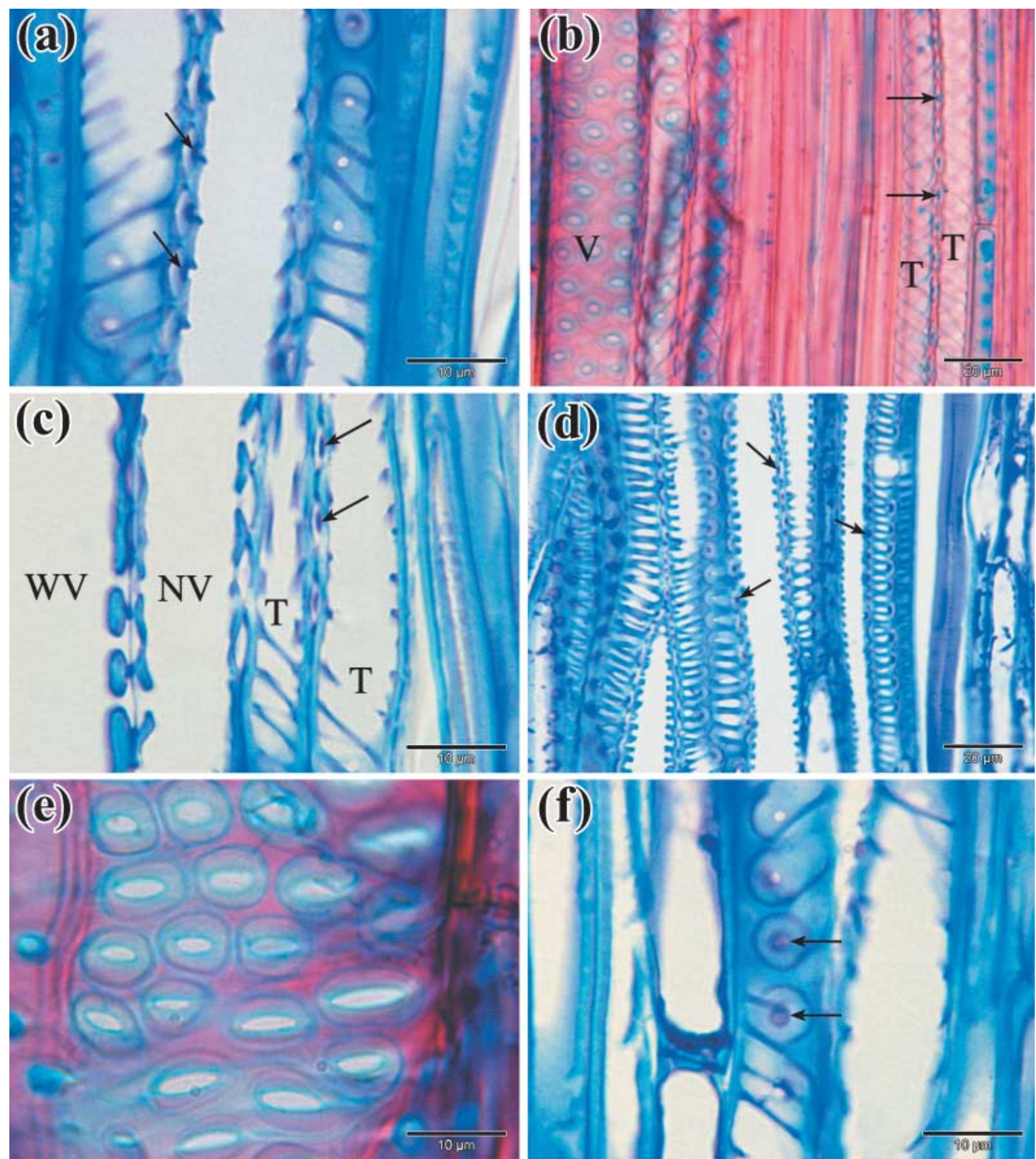

Fig. 2 Light microscopic illustrations of wood of Ulmus. All sections are $\pm 4 \mu \mathrm{m}$ thick and stained with thionin-methylene blue, except for (b) and (e) which are 10-15 $\mu \mathrm{m}$ thick and stained with safranin and alcian blue. (a) Radial longitudinal section of narrow tracheary elements with helical thickenings and tori in UImus laciniata. Arrows indicate pit aspiration. (b) Radial longitudinal section of U. laciniata. Vessel element (V) without tori at left. Tori (arrows) are associated with bordered pits connecting two vascular tracheids (T). (c) Radial longitudinal section of $U$. laciniata. Tori are absent in pit membranes connecting a wide vessel element (WV) and narrow vessel element (NV). Tori (arrows) are restricted to very narrow tracheary elements $(T)$ with helical thickenings. (d) Radial longitudinal section of Ulmus campestris showing narrow vessel elements and vascular tracheids with distinct helical thickenings and tori (arrows). (e) Radial longitudinal section of $U$. laciniata with surface view of bordered pits of a relatively wide vessel element. Note the elliptical to slit-like apertures. ( $f$ ) Radial longitudinal section of $U$. laciniata. Surface view of bordered pits with a torus extending beyond the pit aperture (arrows). 
samples. Tori were also absent in Ampelocera, Aphananthe, Gironniera, Holoptelea, Phyllostylon and Trema.

Tori were centrally located in the pit border, although pit membranes were frequently aspirated, and in such instances the torus occluded the pit aperture (Fig. 2a). The distribution of tori was closely associated with ring porosity and varied with the tracheary elements of the species involved. A torus was usually lacking in pit membranes of vessel elements with a tangential diameter $>20 \mu \mathrm{m}$ wide (Fig. $2 \mathrm{~b}, \mathrm{c}$ ). The intervascular pits of these relatively wide vessel elements were sometimes polygonal, with slit-like pit apertures (Fig. 2e). By contrast, torus-bearing pit membranes were frequently visible in longitudinal sections in pits connecting narrow tracheary elements, which mainly occurred in latewood. These elements were either narrow vessel elements showing one or two very small perforations (so-called 'fibriform' vessel elements), or vascular tracheids, which intergraded with narrow vessel elements (Fig. 2b-d). Helical thickenings were densely present throughout the body of these narrow tracheary elements (Figs 1c, 2a,b,d). The tangential diameter of tracheary elements with tori was usually approx. $10 \mu \mathrm{m}$, varying from 5 to $20 \mu \mathrm{m}$.

The mean longitudinal diameter of tori in Ulmus laciniata was $2.03 \mu \mathrm{m}$, varying from 1.31 to $2.83 \mu \mathrm{m}$ (Table 2). The mean horizontal diameter of tori in this species was $1.92 \mu \mathrm{m}$, with 1.05 and $2.66 \mu \mathrm{m}$ as minimum and maximum values, respectively. The horizontal diameter of the pit border was found to be smaller in pits with tori than in those without $(P<0.0001)$, with mean values of 5.72 and $7.33 \mu \mathrm{m}$, respectively. Also, the horizontal and vertical diameter of the pit aperture was much smaller in pits with tori (mean values of 1.64 and $0.80 \mu \mathrm{m})$ compared with pits without tori (mean values of 3.29 and $1.89 \mu \mathrm{m})(P<0.0001)$. While no difference was found in the circularity ratio of the pit borders $(P=0.499)$, the shape of the pit apertures was more circular or elliptical in pits with tori than in those without $(P<0.0001)$ (Table 2; Fig. 2e,f).

\section{Discussion}

Our LM observations illustrate the presence of torus-bearing pit membranes in ring-porous species of Ulmus and Zelkova, while tori appear to be lacking in diffuse-porous species of Ampelocera, Aphananthe, Gironniera, Phyllostylon, Trema and Ulmus. The observation of tori in Zelkova represents a new record for this genus. Moreover, our data support the idea that tori are common in numerous elm species (Wheeler, 1983; Dute \& Rushing, 1990). Although there is no question that TEM observations are most useful to investigate ultrastructural details of pit membranes, the staining technique applied in this study allows us to explore the distribution of tori following a simple but adequate method. Hence LM observations may form a welcome addition to SEM or TEM observations, especially where comparative studies are concerned, as LM observations are less time-intensive and more cost-effective than reviewing large amounts of material using SEM or TEM. Ohtani (1983) surveyed intervascular pits in 197 Japanese species (110 genera, 50 families) based on SEM observations, but reported tori to be lacking in U. laciniata, U. davidiana var. japonica, Z. acuminata (Ulmaceae), Celtis sinensis var. japonica (Cannabaceae), and A. aspera (Cannabaceae). However, the observations of tori in U. laciniata, U. davidiana and $Z$. acuminata reported in this study cast doubt on Ohtani's interpretation of these species.

As the thin wood samples studied do not include heartwood, this indicates that the tori observed could not be formed as a by-product of the ageing process during the transition of sapwood into heartwood. Moreover, coating materials that cover the pit membrane have been noted from samples collected in winter and as a result of wounding (Rickard et al., 1979; Barnett et al., 1993; Sano \& Fukazawa, 1994; Schmitt et al., 1997; Morrow \& Dute, 1999). The fact that no deposition was found on the pit membranes of large-diameter vessel members indicates that these coatings (wound or seasondependent) are not responsible for the formation of the tori. Dute \& Rushing (1990) illustrated that torus initiation in U. alata, Celtis laevigata and Celtis occidentalis began very early in cell differentiation as an elaboration of the primary walls of the pit membrane. The characteristic blue colour of tori observed in Ulmus and Zelkova suggests that tori in these genera are rich in pectins and cellulose, and have a chemical composition that is essentially similar to that of the primary wall. While the removal of material by sodium chlorite was

\begin{tabular}{lll}
\hline Pit character & Pits without tori & Pits with tori \\
\hline Horizontal diameter of pit border* & $7.33 \mu \mathrm{m}(5.62-10.66)$ & $5.72 \mu \mathrm{m}(3.34-7.55)$ \\
Horizontal diameter of pit aperture* $^{*}$ & $3.29 \mu \mathrm{m}(1.84-7.32)$ & $1.64 \mu \mathrm{m}(0.91-2.46)$ \\
Vertical diameter of pit aperture* $^{*}$ & $1.89 \mu \mathrm{m}(1.18-3.6)$ & $0.80 \mu \mathrm{m}(0.38-1.18)$ \\
Horizontal diameter of torus & (torus absent) & $1.92 \mu \mathrm{m}(1.05-2.66)$ \\
Vertical diameter of torus & (torus absent) & $2.03 \mu \mathrm{m}(1.31-2.83)$ \\
Circularity ratiot of pit border $_{\text {Circularity ratio of pit aperture }}^{*}$ & $0.87(0.56-0.99)$ & $0.88(0.69-0.99)$ \\
& $0.61(0.25-0.97)$ & $0.85(0.53-1)$
\end{tabular}

Table 2 Mean values of pit characters of Ulmus laciniata (minimum and maximum values in parentheses)

${ }^{*} P<0.0001$. +Circularity ratio defined as ratio of short to long axis. All data based on 50 measurements. 
interpreted to indicate the presence of lignin in the torus of $U$. alata (Wheeler, 1983), Coleman et al. (2004) have recently suggested that tori in Ulmus and Celtis are not lignified.

Interestingly, angiosperms with tori appear to show the following characteristic features: (1) a relatively small pit aperture that is circular to elliptical in outline; (2) an indistinct pit canal that is very short or entirely lacking; and (3) the prominent occurrence of helical thickenings throughout the body of narrow tracheary elements. The association between the evolution of the torus and small and circular pit apertures was previously suggested in gymnosperms, and further illustrated in Thymelaeaceae (Wright, 1928; Beck et al., 1982; Dute et al., 1996, 2001). Hence a torus is not found in association with linear, slit-like apertures. The converse, however, need not be true - not all species with small and circular pit apertures form torus-bearing pit membranes (Dute et al., 2001). Although quantitative data on the circularity ratio in $U$. laciniata overlap between pits with a torus and those lacking a torus, our data support the above correlation (Table 2). It should be emphasized that tori appear to be closely associated with ring porosity. Except for U. mexicana, all species without tori do not show very narrow vessel elements or vascular tracheids with distinct helical thickenings. Based on these correlations, it is likely that tori could be found in two other genera of the Ulmaceae, namely Planera and Hemiptelea, as ring-porous wood with vascular tracheids and narrow vessel elements with distinct helical thickenings are recorded in these two genera (Sweitzer, 1971; Zhong et al., 1992). The association of tori with other pit characters may indicate that the development of tori is inherited as a functional complex in woody plants (Carlquist \& Robinson, 1995).

As regards functional aspects, tori are suggested to serve as a closure valve in case of pit aspiration, but may also provide additional strength to the pit membrane, and thus prevent rupture during membrane displacement (Wheeler, 1983; Dute et al., 1990, 2001; Morrow \& Dute, 1998). As the diameter of the torus is greater than that of the pit aperture in U. laciniata (Table 2), the torus-bearing pit membrane would be more effective than one of uniform thickness in sealing off a pit aperture and therefore confining air embolism. Also, differences observed in pit geometry may have consequences for the stress experienced by the membrane during displacement (Hart \& Thomas, 1967; Jansen et al., 2003; B.C. and co-workers, unpublished). Sperry (2003) suggested that greater pit conductivity per air-seed pressure could explain the persistence of torus-margo pits in conifers and their convergent evolution in certain angiosperms. As Carlquist (1996) reported for Gnetales, the development of tori in Ulmaceae may represent simply the promotion of conductive safety, which differs between wide vessels and narrow tracheary elements (Carlquist, 1984, 1985). Vulnerability to freeze-induced embolism is well correlated with conduit diameter (Sperry et al., 1994; Davis et al., 1999). Also, there is a correlation between drought-induced embolism and conduit diameter within one tree (Hargrave et al., 1994), but this does not hold true at the interspecies level (Tyree \& Zimmerman, 2002). Narrow vessels formed in the latewood of $U$. americana are suggested to be nearly as resistant as tracheids to embolism formation (Ellmore \& Ewers, 1985).

Species commonly containing narrow tracheary elements ('fibriform' vessel elements and vasicentric tracheids sensu Carlquist) in combination with helical thickenings frequently occur in areas that are dry or cold (Baas, 1973; van den Oever et al., 1981; Carlquist, 1984, 1985, 2001). Based on the taxa examined in this study, the distribution of tori suggests that this feature tends to occur in cold temperate climates of Eurasia and North America. Hence the absence of tori in species such as $U$. mexicana and U. lancifolia, distributed in Mexico and Indonesia, respectively, could be caused by the relatively warmer climate as compared with the other elm species investigated. A similar conclusion could be suggested for the absence of tori in the other genera of Ulmaceae (Ampelocera, Aphananthe, Holoptelea, Phyllostylon) and Cannabaceae (Gironniera, Trema) studied. Interestingly, Ulmaceae are suggested to have a South or Central American origin, with a subsequent dispersal of the Northern Hemisphere taxa (including Hemiptelea, Planera, Ulmus, Zelkova) from Asia to Europe and North America, or an initial radiation of these taxa in North America before their spread to Eurasia according to a second phylogeographic model (Manchester \& Tiffney, 2001). Although further observations are required on the ecological distribution of tori, most other angiosperm genera with tori (Daphne, Wikstroemia, Ulmus, Celtis and Osmanthus) tend to occur in temperate to boreal regions. The development of tori could therefore indicate a functional adaptation to relatively cold climates where freezing-induced cavitation may occur. As the highest frequencies of vestured pits occur in tropical, seasonal woodlands and deserts, where drought-induced cavitation is common, vestures could substitute for a torus as regards protection for the pit membrane in order to avoid embolism (Dute et al., 2001; Jansen et al., 2003). So far, vestures and tori appear to be mutually exclusive as they co-occur in the same pits in very few families (e.g. Thymelaeaceae). However, the morphology of these vestures is unlikely to reduce pit membrane deflection, as they are generally minute, simple, and do not point towards the pit membrane (Jansen et al., 2000).

Although the genus Ulmus is relatively well defined, the delimitation of species and their taxonomic affinities are subject to major conflicting taxonomic treatments (Armstrong \& Sell, 1996). Our data on the distribution of tori do not suggest any systematic implication within Ulmus. Tori occur in the two subgenera, Oreoptelea and Ulmus, as well as all sections distinguished by Wiegrefe et al. (1994). Moreover, the absence of tori in $U$. mexicana and $U$. lancifolia suggests that this feature is at least partly determined by environmental aspects. At a higher taxonomic level, Ulmus is suggested to form a clade with the genera Planera, Hemiptelea and Zelkova (Ueda et al., 1997; Wiegrefe et al., 1998; Manchester \& Tiffney, 
2001). The observation of tori in Ulmus and Zelkova and the possible occurrence of this feature in Hemiptelea and Planera could support this clade. It would be interesting to investigate whether tori are present in the latter two genera. Tori were also reported to occur in three species of Celtis, which was previously included within Ulmaceae (Wheeler, 1983; Dute \& Rushing, 1990). As recent classifications place Celtis within either Celtidaceae or Cannabaceae, this would suggest that tori have developed independently in Celtis and Ulmaceae (Judd et al., 2002; APG II, 2003).

A better understanding of pit characters such as tori and vestures, including their systematic and ecological distribution, could be important in order to comprehend characters that contribute to conductive safety or efficiency in secondary xylem. We are currently surveying other angiosperm families for the distribution of tori. Special attention should be paid to plant groups that show narrow tracheary elements with helical thickenings, intervascular pits with circular and small pit apertures, and an indistinct pit canal. We hope that additional studies may help to piece together the evolution of this interesting feature.

\section{Acknowledgements}

We thank Dr R.R. Dute (Auburn University, USA) for relevant information about tori and Miss A. Vandeperre (K.U.Leuven) for technical assistance. The Director of the National Botanic Garden of Belgium (BR) is acknowledged for permission to execute anatomical studies on herbarium material. S.J. is a postdoctoral fellow of the Fund for Scientic Research Flanders (Belgium) (FWO - Vlaanderen) and S.V. is a postdoctoral fellow of the Research Council of the K.U.Leuven (PDM/03/145). Research at the Laboratory of Plant Systematics is supported by grants from the Research Council of the K.U.Leuven (OT/01/25) and the Fund for Scientific Research - Flanders (Belgium) (FWO - Vlaanderen) (G.104.01, 1.5.069.02, 1.5.061.03).

\section{References}

APG II. 2003. An update of the Angiosperm Phylogeny Group classification for the orders and families of flowering plants: APG II. Botanical Journal of the Linnean Society 141: 399-436.

Armstrong JV, Sell PD. 1996. A revision of the British elms (Ulmus L., Ulmaceae): the historical background. Botanical Journal of the Linnean Society 120: 39-50.

Baas P. 1973. The anatomical range in Ilex (Aquifoliaceae) and its ecological and phylogenetic significance. Blumea 21: 193-258.

Barnett JR. 1987. The development of fibre-tracheid pit membranes in Pyrus communis L. International Association of Wood Anatomists Bulletin, New Series 7: 195-220.

Barnett JR, Cooper P, Bonner L. 1993. The protective layer as an extension of the apoplast. International Association of Wood Anatomists Bulletin, New Series 8: 163-171.

Bauch JW, Liese W, Schultze R. 1972. The morphological variability of the bordered pit membranes in gymnosperms. Wood Science and Technology 6 : 162-184.
Beck CB, Coy K, Schmid R. 1982. Observations on the fine structure of Callixylon wood. American Journal of Botany 69: 54-76.

Becker P, Gribben RJ, Schulte PJ. 2003. Incorporation of transfer resistance between tracheary elements into hydraulic resistance models for tapered conduits. Tree Physiology 23: 1009-1019.

Booker RE. 1992. Hypothesis to explain the characteristic appearance of aspirated pit. In: Rojo JP, Aday JU, Barile ER, Araral RK, America WM, eds. Proceedings of the 2nd Pacific Regional Wood Anatomy Conference. Laguna, Philippines: Forest Products Research and Developmental Institute College, 269-281.

Carlquist S. 1984. Wood and stem anatomy of Bergia suffrucitosa: relationships of Elatinaceae and broader significance of vascular tracheids, vasicentric tracheids, and fibriform vessel elements. Annals of the Missouri Botanical Garden 71: 323-242.

Carlquist S. 1985. Vasicentric tracheids as a drought survival mechanism in the woody flora of southern California and similar regions; review of vasicentric tracheids. Aliso 11: 37-68.

Carlquist S. 1996. Wood, bark, and stem anatomy of Gnetales: a summary. International Journal of Plant Sciences 157: S58-S76.

Carlquist S. 2001. Comparative Wood Anatomy. Systematic, Ecological, and Evolutionary Aspects of Dicotyledon Wood. Berlin, Germany: SpringerVerlag.

Carlquist S, Robinson AA. 1995. Wood and bark anatomy of the African species of Gnetum. Botanical Journal of the Linnean Society 118: 123-137.

Choat B, Ball M, Luly J, Holtum J. 2003. Pit membrane porosity and water stress-induced cavitation in four co-existing dry rainforest tree species. Plant Physiology 131: 41-48.

Cochard H, Cruiziat P, Tyree MT. 1992. Use of positive pressures to establish vulnerability curves: further support for the air-seeding hypothesis and implications for pressure-volume analysis. Plant Physiology 100: 205-209.

Coleman CM, Prather BL, Valente MJ, Dute RR, Miller ME. 2004. Torus lignification in hardwoods. International Association of Wood Anatomists Journal 25: (In press.)

Davis SD, Sperry JS, Hacke UG. 1999. The relationship between xylem conduit diameter and cavitation caused by freezing. American Journal of Botany 86: 1367-1372.

Dute RR, Rushing AE. 1987. Pit pairs with tori in the wood of Osmanthus americanus (Oleaceae). International Association of Wood Anatomists Bulletin, New Series 8: 237-244.

Dute RR, Rushing AE. 1988. Notes on torus development in the wood of Osmanthus americanus (L.) Benth. \& Hook. ex Gray (Oleaceae). International Association of Wood Anatomists Bulletin, New Series 9: 41-51.

Dute RR, Rushing AE. 1990. Torus structure and development in the woods of Ulmus alata Michx., Celtis laevigata Willd. and Celtis occidentalis L. International Association of Wood Anatomists Bulletin, New Series 11: 7183.

Dute RR, Rushing AE, Perry JW. 1990. Torus structure and development in species of Daphne. International Association of Wood Anatomists Bulletin, New Series 11: 401-412.

Dute RR, Rushing AE, Freeman JD. 1992. Survey of intervessel pit membrane structure in Daphne species. International Association of Wood Anatomists Bulletin, New Series 13: 113-123.

Dute RR, Freeman JD, Henning F, Barnard LD. 1996. Intervascular pit membrane structure in Daphne and Wikstroemia - systematic implications. International Association of Wood Anatomists Journal 17: 161-181.

Dute RR, Miller ME, Carollo RR. 2001. Intervascular pit structure in selected species of Thymelaeaceae. Journal of Alabama Academy of Science 72: 14-26.

Ellmore GS, Ewers FW. 1985. Hydraulic conductivity in trunk xylem of elm, Ulmus americana. International Association of Wood Anatomists Bulletin, New Series 6: 303-307.

Fengel D. 1972. Structure and function of the membrane in softwood bordered pits. Holzforschung 26: 1-9. 
Frost FH. 1931. Specialization in secondary xylem of dicotyledons III. Specialization of lateral wall of vessel segment. Botical Gazette 91: 88-96.

Hargrave KR, Kolb KJ, Ewers FW, Davis SD. 1994. Conduit diameter and drought-induced embolism in Salvia mellifera Greene (Labiatae). New Phytologist 126: 695-705.

Hart CA, Thomas RJ. 1967. Mechanism of bordered pit aspiration as caused by capillarity. Forest Products Journal 17: 61-88.

IAWA Committee. 1989. IAWA list of microscopic features for hardwood identification. International Association of Wood Anatomists Bulletin, New Series 10: 219-332.

Jansen S, Kitin P, De Pauw H, Idris M, Beeckman H, Smets E. 1998a. Preparation of wood specimens for transmitted light microscopy and scanning electron microscopy. Belgian Journal of Botany 131: 41-49.

Jansen S, Smets E, Baas P. 1998b. Vestures in woody plants: a review. International Association of Wood Anatomists Journal 19: 347-382.

Jansen S, Baas P, Smets E. 2000. Vestured pits in the Malvales s.1. a character with taxonomic significance hidden in the secondary xylem. Taxon 49: 169-182.

Jansen S, Baas P, Smets E. 2001. Vestured pits: their occurrence and systematic importance in eudicots. Taxon 50: 135-167.

Jansen S, Baas P, Gasson P, Smets E. 2003. Vestured pits: do they promote safer water transport? International Journal of Plant Sciences 164: 405-413.

Judd WS, Campbell CS, Kellogg EA, Stevens PF, Donoghue MJ. 2002. Plant Systematics: A Phylogenetic Approach, 2nd edn. Sunderland, MA, USA: Sinauer Associates.

Liese W. 1965. The fine structure of pits in softwoods. In: Côté WA, ed. Cellular ultrastructure of woody plants. New York, USA: Syracuse University Press, 291-304.

Manchester SR, Tiffney BH. 2001. Integration of paleobotanical and neobotanical data in the assessment of phytogeographic history of holarctic angiosperm clades. International Journal of Plant Sciences 162: S19-S27.

Morrow AC, Dute RR. 1998. Development and structure of pit membranes in the rhizome of the woody fern Botrychium dissectum. International Association of Wood Anatomists Journal 19: 429-441.

Morrow AC, Dute RR. 1999. Electron microscopic investigation of the coating found on torus-bearing pit membranes of Botrychium dissectum, the common grape fern. International Association of Wood Anatomists Journal 20: 359-373.

van den Oever L, Baas P, Zandee M. 1981. Comparative wood anatomy of Symplocos and latitude of provenance. International Association of Wood Anatomists Bulletin, New Series 2: 3-24.

Ohtani J. 1983. SEM investigation on the micromorphology of vessel wall sculptures. Research Bulletins of the College Experiment Forests, College of Agriculture, Hokkaido University 40: 323-386.

Ohtani J, Ishida S. 1978. Pit membrane with torus in dicotyledonous woods. Mokuzai Gakkaishi 24: 673-675.

Parameswaran N, Gomes AV. 1981. Fine structural aspects of helical thickenings and pits in vessels of Ligustrum lucidum Ait. (Oleaceae). International Association of Wood Anatomists Bulletin, New Series 2: 179-185.

Parameswaran N, Liese W. 1981. Torus-like structures in inter-fibre pits of Prunus and Pyrus. International Association of Wood Anatomists Bulletin, New Series 2: 89-93.
Rickard JE, Marriott J, Gahan PB. 1979. Occlusions in cassava xylem vessels associated with vascular discoloration. American Journal of Botany 43: $523-526$.

Sano Y, Fukazawa K. 1994. Structural variation and secondary changes in pit membranes in Fraxinus mandshurica var. japonica. International Association of Wood Anatomists Journal 15: 283-291.

Sano Y, Kawakami Y, Ohtani J. 1999. Variation in the structure of intertracheary pit membranes in Abies sachalinensis, as observed by fieldemission scanning electron microscopy. International Association of Wood Anatomists Journal 20: 375-388.

Schmid R. 1965. The fine structure of pits in hardwoods. In: Côté WA, ed. Cellular ultrastructure of woody plants. New York, USA: Syracuse University Press, 291-304.

Schmid R, Machado RD. 1968. Pit membranes in hardwoods - fine structure and development. Protoplasma 66: 185-204.

Schmitt U, Richter HG, Muche C. 1997. TEM study of wound-induced vessel occlusions in European Ash (Fraxinus excelsior L.). International Association of Wood Anatomists Journal 18: 401-404.

Schols P, Dessein S, D’hondt C, Huysmans S, Smets E. 2002. Carnoy: a new digital measurement tool for palynology. Grana 41: $124-126$.

Sperry JS. 2003. Evolution of water transport and xylem structure. International Journal of Plant Sciences 164: S115-S127.

Sperry JS, Nichols KL, Sullivan JEM, Eastlack SE. 1994. Xylem embolism in ring-porous, diffuse-porous, and coniferous trees in northern Utah and interior Alaska. Ecology 75: 1736-1752.

Sweitzer EM. 1971. Comparative anatomy of Ulmaceae. Journal of the Arnold Arboretum 52: 523-585.

Tyree MT, Sperry JS. 1989. Vulnerability of xylem to cavitation and embolism. Annual Review of Plant Physiology and Molecular Biology 40: $19-38$.

Tyree MT, Zimmermann MH. 2002. Xylem structure and the ascent of sap. Berlin, Germany: Springer-Verlag.

Ueda K, Kosuge K, Tobe H. 1997. A molecular phylogeny of Celtidaceae and Ulmaceae (Urticales) based on $r b c \mathrm{~L}$ nucleotide sequences. Journal of Plant Research 110: 171-178.

Wheeler EA. 1983. Intervascular pit membranes in Ulmus and Celtis native to the United States. International Association of Wood Anatomists Bulletin, New Series 4: 79-88.

Wiegrefe SJ, Sytsma KJ, Gories RP. 1994. Phylogeny of elm (Ulmus, Ulmaceae): molecular evidence for a sectional classification. Systematic Botany 19: 590-612.

Wiegrefe SJ, Sytsma KJ, Gories RP. 1998. The Ulmaceae, one family or two? Evidence from chloroplast DNA restriction site mapping. Plant Systematics and Evolution 210: 249-270.

Wright JG. 1928. The pit-closing membrane in the wood of the lower gymnosperms. Proceedings and Transactions of the Royal Society of Canada, Series 3. 22: 63-94.

Zhong Y, Baas P, Wheeler EA. 1992. Wood anatomy of trees and shrubs from China. IV. Ulmaceae. International Association of Wood Anatomists Bulletin, New Series 13: 419-453.

Zwieniecki MA, Melcher PJ, Holbrook NM. 2001. Hydrogel control of xylem hydraulic resistance in plants. Science 291: 1059-1062. 